\title{
Factors Influencing the Voluntary Disclosure of Vietnamese Listed Companies
}

\author{
Pham Duc Hieu \\ Vietnam University of Commerce, Hanoi, Vietnam \\ Do Thi Huong Lan \\ State Securities Commission of Vietnam, Hanoi, Vietnam
}

\begin{abstract}
This paper aims to investigate the factors affecting the extent of voluntary disclosure by examining the annual reports of 205 industrial and manufacturing companies listing on Ho Chi Minh Stock Exchange (HSX) and Hanoi Stock Exchange (HNX) for the year of 2012. Those factors include company size, profitability, leverage, state ownership, managerial ownership, and foreign ownership, board independence, role duality, and type of external auditors. Evidence from this study suggests two main findings: (1) Companies with high foreign ownership have a high level of voluntary disclosure; (2) The company size is an important factor related to the increased level of voluntary disclosure in annual reports of Vietnamese listed companies. However, no significant associations are found between profitability, leverage, state ownership, managerial ownership, board independence, role duality, and type of external auditors as hypothesized in this study.
\end{abstract}

Keywords: voluntary disclosure, Vietnamese listed companies, securities market

\section{Introduction}

Securities market is normally considered as a market which is extremely sensitive to the information. Those who owe more information will have effective investment decisions. But, information may have negative effects and may not only result in damages to the corporations but also erode the investor's belief. As a result, it can be said that information disclosure is important for stock market and market participants. If the information is disclosed timely, sufficiently, and properly, there will be active effects on the market development or vice versa.

In recent years, several scandals and scams concerning the activities of the business enterprises have occurred around the world. Due to these corporate failures, the importance of corporate disclosure has been increasing day by day. Annual report is the most important medium of the reported transparency (Nandi \& Ghosh, 2013). Low transparency and information asymmetry have a common connection. Low transparency implies that not enough information is communicated to the investing community which consecutively indicates that there exists information asymmetry between those who know the information and who do not. Such higher information asymmetry should, therefore, result in more "information premium" (Madhani, 2007, p. 65).

Pham Duc Hieu, Ph.D., CPA, associate professor, Faculty of Accounting and Auditing, Vietnam University of Commerce. Email: hieuphamduc@gmail.com.

Do Thi Huong Lan, specialist, Securities Market Development Department, State Securities Commission of Vietnam. 
Information disclosure is one of the basic principles of the stock market. It can be a powerful tool for protecting investors and monitoring companies. Adequate disclosure is important because without such information, it is impossible to properly judge the opportunities and risks of investment:

Enterprises should ensure that timely and accurate information is disclosed on all material matters regarding their activities, structure, financial situation, performance, ownership and governance. This information should be disclosed for the enterprise as a whole, and where appropriate, along business lines or geographic areas. Disclosure policies of enterprises should be tailored to the nature, size and location of the enterprise, with due regard taken of costs, business confidentiality and other competitive concerns. (International Organization of Securities Commissions [OICV-IOSCO], 2002, p. 2)

Information disclosure includes mandatory disclosure and voluntary disclosure. Mandatory disclosure is the case on which rules and regulations are set up for listed companies to reveal their information to the public on a regular basis. Voluntary disclosure refers to the activities of voluntary revealing information in addition to that required by regulators, and the motivation includes managing corporate image, maintaining investor relation, and reducing litigation risk ( $\mathrm{Li} \&$ Zhao, 2011). To enhance competitiveness, companies view disclosure as an opportunity rather than a burden. The higher the level of disclosure, the lower is the information risk premium. Low risk premium provides higher valuation. Companies gain from building reputation for transparent reporting, as it eventually results in higher management credibility, a higher price/earnings (P/E) multiple, increased liquidity, and a lower cost of capital (Madhani, 2007).

Presently, in Vietnam, mandatory information disclosure is not fully enforced, let alone voluntary information disclosure. However, witnessing the major world scandals of Enron, WorldCom as well as local one like Bong Bach Tuyet Company and Vien Dong Pharmaceutical Company, the Vietnamese investors are now more involved in company's affairs and they are asking for their rights to be timely and properly informed about the company's activities. There have been a great number of scholars around the world studying the factors influencing the voluntary disclosure of listed companies. However, there have been a few researches focusing on this matter in Vietnam. The aim of this study is to examine the factors influencing the voluntary disclosure, that is to examine the association between company characteristics (company size, profitability, and leverage), ownership structure (state ownership, managerial ownership, and foreign ownership), corporate governance (board independence, role duality, and type of external auditors), and the extent of voluntary disclosure of 205 industrial and manufacturing companies listing on Ho Chi Minh Stock Exchange (HSX) and Hanoi Stock Exchange (HNX) for the year of 2012. These research objectives lead to the following research questions:

(1) What is the extent of voluntary disclosure of Vietnamese listed companies?

(2) What are factors affecting the voluntary disclosure of Vietnamese listed companies?

This study is organized as follows: A brief of the theoretical framework, an overview of reporting practice in Vietnam, and an overview of the literature are provided in Section 2. Hypotheses development is presented in Section 3. The methodology, the construction of disclosure index, and sample selection are provided in Section 4. The results are discussed in Section 5. Summary and conclusion are presented in Section 6.

\section{Theoretical Framework and Literature Review}

\section{Agency Theory}

Agency theory explains the relationship between principals as shareholders and agents, such as a company's executives. Jensen and Meckling (1976) defined an agency relationship as a contract under which 
one or more persons (the principle(s)) engage another person (the agent) to perform some services on the behalf which involves delegating some decision-making authority to the agent. They assumed that if both parties to the relationship are utility maximizers, there is a good reason to believe that the agent will not always act in the best interests of the principal. Agency theory explains the reason why accounting reports would be provided voluntarily to creditors and stockholders (Jensen \& Meckling, 1976), and it also explains voluntary disclosure in the context of separation between ownership and control (Sukthomya, 2011). A separation of ownership and control of a company results in agency problems due to conflicts of interests between the contract parties. The principal can limit divergences from his interest by establishing appropriate incentives for the agent and by incurring monitoring costs designed to limit the aberrant activities of the agent. Jensen and Meckling (1976) defined agency costs as the sum of: (1) the monitoring expenditures by the principal (to limit the aberrant activities of the agent); (2) the bonding expenditures by the agent (to guarantee that no action will be taken by the agent to harm the principal's interests); and (3) the residual loss (the cost relating to the reduction in welfare experienced by the principal as a result of the divergence between the agent's decisions and those decisions would maximize the welfare of the principal).

In the context of the company, a major issue is the information asymmetry between managers and shareholders. In this agency relationship, insiders (managers) have an information advantage. Owners, therefore, face moral dilemmas because they cannot accurately evaluate and determine the value of decisions made. The agent, therefore, takes advantage of the lack of observability of his actions to engage in activities to enhance his personal goals (Barako, 2007). On the other hand, shareholders who are outsiders have to bear the risk of losing their money due to a lack of information (Lokman, 2011).

An important aspect of agency theory is the need to control the behavior of managers through monitoring mechanisms such as corporate governance and voluntary disclosure. The adoption of these governance mechanisms enables shareholders to mitigate agency problems and at the same time reduce agency costs associated with any decrease of company value as well as monitoring and bonding costs (Lokman, 2011).

\section{Overview of Reporting Practice in Vietnam}

The Vietnamese corporate disclosure environment has changed dramatically during the past decade. Vietnamese accounting standards have been harmonized with the International Financial Reporting Standards (IFRS), and the regulatory agencies of the Vietnamese Government have gradually established a comprehensive regulatory framework for corporate information disclosures in the Vietnamese securities market. The economic reform launched in Vietnam since 1986 has led to some significant changes to Vietnamese society. In an effort to industrialize and modernize the country, maintain stable economic growth, and restructure the economy to enhance its efficiency and competition, Vietnam had needed huge capital of investment. Therefore, building securities market in Vietnam had become an urgent demand to mobilize mid-term and long-term capital within as well as outside the country into economic investment through debt securities and capital securities. In addition, the privatization of state-owned enterprises along with the establishment and development of securities market would create a more open and healthier business environment. On July 10, 1998, the Prime Minister signed Decree No. 48/1998/ND-CP on stock and securities market and a decision to set up two securities trading centers at Hanoi and Ho Chi Minh City. On July 20, 2000, the Ho Chi Minh City Securities Trading Center was officially put into operation and executed the first trading session on July 28, 2000 with two types of listing stocks. In August 2007, it was renamed as HSX. 
Hanoi Securities Trading Center was established in 2005, and later renamed as HNX in 2009. At present, there are 342 companies listed in HSX, and 393 companies listed in HNX with the total capitalization of about 964,000 billion VND, which is equivalent to $31 \%$ GDP.

With regard to information disclosure regulations, Securities Law ref. 70/QH11 dated June 29, 2006 promulgated by the National Assembly of Vietnam has provided an important legal corridor for the development of Vietnam Securities Market. From the very first days of application, Securities Law has approved the aims, objectives, and principles of securities market operation that are justice, public, and transparent, to protect the rights and interests of investors. For more than a decade of formation and development, Vietnam Securities Markets have strongly qualitatively and quantitatively developed and have become one of the effective capital channels of the economy. After three-year implementation, besides many positive aspects of the Securities Law which have been proved to partly contribute to the development of the market, there were some shortcomings which needed the adjustment for making it suitable to the rapid changing of the securities market; among those shortcomings is information disclosure. To remedy that shortcoming, on November 24, 2010, the National Assembly of Vietnam enacted the Securities Law 62/2012/QH12 altering and supplementing the Securities Law 70/QH11, which has more fully met the market development requirements and supplemented the regulations on information disclosure.

Acknowledging the increasingly important roles of transparent information disclosure of public companies in such a young securities market of Vietnam in protecting the rights and interests of shareholders, investors, and stakeholders, in 2010, the Ministry of Finance (MoF) promulgated Circular No. 09/2010/TT-BTC dated January 15, 2010 guiding information disclosure in Vietnam Securities, which replaced Circular No. 38/2007/TT-BTC previously promulgated. However, the information disclosure regulations regulated by Circular No. 09/2010/TT-BTC did not cover all the contents of the Securities Law 62/2012/QH12, such as expanding the subjects of information disclosure, classifying the information disclosure of public companies based on the capital size and publicity of the company (instead of classifying into the listed and non-listed public companies). That is the reason why Circular No. 52/2012/TT-BTC dated April 5, 2012 has been promulgated and it has supplemented the detailed regulations on information disclosure of public companies and aimed at building a public and transparent securities market to better protect the rights and interests of investors. The MoF and the State Securities Commission of Vietnam (SSC) are the two main government regulatory agencies managing and regulating the stock market.

\section{Literature Review}

To date, there have been a number of researches in developed and developing countries to measure corporate disclosure on financial and non-financial companies, for example: Al-Janadi, Rahman, and Omar (2013); Alves, Rodrigues, and Canadas (2012); Barako (2007); Bilal, Tufail, Khan, Abbas, and Saeed (2013); Botosan (1997); Fekete, Matis, and Lukács (2008); Healy and Palepu (2001); Hossain and Hammami (2009); Ianniello, Mainardi, and Rossi (2013); Jensen and Meckling (1976); Leng and Ding (2011); Li and Zhao (2011); Li and Qi (2008); Lokman (2011); Nandi and Ghosh (2013); Omran and Abdelrazik (2013); Rouf (2011); Sukthomya (2011); Vu (2012); Qu (2011); Lan, Wang, and Zhang (2013); and Zhang (2013). A few of their studies will be chosen to help understand the nature, methodology, and findings of this study. 
$\mathrm{Vu}$ (2012) investigated the issue of corporate transparency in the fast-growing economy of Vietnam, specifically in relation to voluntary disclosure practices, and tried to seek the extent and determinants of key contemporary corporate disclosure practices pertinent to Vietnamese listed companies. Her study investigated the influence of corporate governance (the proportion of independent directors on corporate boards), three common ownership identities of Vietnamese listed companies (state, managerial, and foreign ownership), and company characteristics variables (company size, profitability, leverage, industry, auditing company, listing duration, and stock exchange location) on the extent of voluntary disclosure made by 252 Vietnamese non-financial listed companies across the annual reporting year 2009. Her results revealed that the proportion of independent directors on corporate boards is an important aspect associated positively with voluntary disclosure while the proportions of state ownership and managerial ownership are the ownership identities that influence the extent of voluntary disclosure negatively. Company characteristics statically related to the extent of voluntary disclosure are company size, profitability, industry, auditing company, listing duration, and stock exchange location.

The study of Barako (2007) provided a longitudinal examination of voluntary disclosure practices in the annual reports of listed companies in Kenya from 1992 to 2001. The study investigated the extent to which corporate governance attributes, ownership structure, and company characteristics influence voluntary disclosure of various types of information. Their results indicated that disclosures of all types of information are influenced by corporate governance attributes, ownership structure, and corporate characteristics. In particular, the results also suggested that size and companies in the agricultural sector are significantly associated with the voluntary disclosure of all four types of information disclosures.

Rouf (2011) aimed to evaluate the corporate voluntary disclosure of management's responsibilities in the Bangladeshi listed companies during 2005-2008 through the annual reports of 132 listed companies in Dhaka Stock Exchange. The results showed that voluntary disclosure level has a negative relation with the percentage of equity owned by the insiders, and a positive relation with the percentage of equity held by institutional shareholders, board of audit committee, and board leadership structure.

The research of Sukthomya (2011) tried to answer the question of how to explain the voluntary disclosure of companies listed on an emerging capital market of Thailand. It investigated the extent of voluntary disclosure of 100 companies listed in the SET100 Index of the Stock Exchange of Thailand, and the influence of company characteristics, financial attributes, and corporate governance related factors on voluntary practices. The results reveal that company size is associated with the increase in the level of voluntary disclosure, while in companies in which the chairmen and CEOs are the same person, they disclose significantly less voluntary information in their annual reports. Profitability, leverage, ownership structure, proportion of non-executive directors, and type of auditors are found to have no explanatory power.

$\mathrm{Qu}$ (2011) examined the voluntary disclosure of strategic, financial, and non-financial information in 297 listed companies' annual reports in the reporting periods of 1995-2006. The findings of this study show that voluntary disclosure made by listed companies in the Chinese stock market increased over the testing period, meaning that companies have positively reacted to the changed corporate disclosure environment in China. Companies' ownership structure, corporate governance-related factors, and economic attributes are used to represent either stakeholder's political or financial stake in listed companies. The findings show that state ownership has a significant negative impact on companies' disclosure decisions, whereas foreign investment has a significant positive influence on companies' voluntary disclosure. The corporate governance regime in 
the Chinese stock market has exerted pressure on listed companies in respect of information disclosure and investor protection. International audit companies were found to play a positive and significant role in improving disclosure transparency among listed companies.

According to Li and Zhao (2011), the level of voluntary disclosure is affected by both internal and external factors. Internal factors contain financial condition and corporate governance of the company, while external factors include regulatory penalties, audit opinion, the development of regional market, and degree of industry.

In their study, Lan et al. (2013) based on the information in the annual reports of 1,066 Chinese companies listed on the Shanghai and Shenzhen Stock Exchanges suggested that voluntary disclosure in China is positively related to company size, leverage, assets-in-place, and return on equity and is negatively related to auditor type and the level of maturity or sophistication of the intermediary and legal environments. They also found some evidence to suggest a quadric convex association between state ownership and voluntary disclosure. However, their analysis provides no evidence that extensive disclosure benefits public companies in China in the form of a lower cost of equity.

Hossain and Hammami (2009) studied the determinants of voluntary disclosure in the annual reports of 25 listed companies of Doha Securities Market in Qatar. Their findings indicate that age, size, complexity, and assets-in-place are significant, and the other variable profitability is insignificant in explaining the level of voluntary disclosure.

Alves et al. (2012) examined the relations between corporate characteristics, corporate governance variables, and voluntary disclosure in the annual reports of Portuguese and Spanish listed companies. Their results indicate that the main determinants of voluntary disclosure are the variables related with company size, growth opportunities, organization performance, board compensation, and the presence of a large shareholder.

The aim of Elmans' (2012) study is to gain more insight in the disclosure practices of European companies by examining the relation between ownership structure and the extent of voluntary disclosures. This study demonstrates that there is a negative association between blockholder ownership and voluntary disclosures. In addition, a positive association exists between government ownership and voluntary disclosures. No significant association is observed between managerial ownership and voluntary disclosures. Overall, it is recommended that investors who aim to acquire a high degree of voluntary disclosures invest in companies with low blockholder ownership and high government ownership.

Rouf and Harun (2011) studied the association between ownership structure and voluntary disclosure levels in the 2007 annual reports of 94 samples of Bangladeshi listed companies. Ownership structure is provided by management ownership and institutional ownership. Using agency theory, it is argued that companies with higher management of ownership structure may disclose less information and higher institutional ownership structure may disclose more information to shareholders through voluntary disclosure. It is because the determined ownership structure provides companies with lower incentives to voluntarily disclose information to meet the needs of non-dispersed shareholders. The result shows that the extent of corporate voluntary disclosures is negatively associated with a higher management of ownership structure and the extent of corporate voluntary disclosures is positively associated with a higher institutional ownership structure. 


\section{Hypothesis Development}

\section{The Relation Between Company Characteristics and the Level of Voluntary Disclosure}

The company characteristics examined in this study include the size of the company, the profitability, and leverage. Those characteristics will be used as independent variables.

Company size and the extent of voluntary disclosure. Size of the company is normally considered to be one of the important factors of corporate disclosure. Most researchers have found a positive relationship between company size and the level of corporate disclosure. In some researches, size of the company is measured by net sale (A ğca \& Önder, 2007), whereas others use total assets (Vu, 2012; Zhang, 2013; Hossain \& Hammami, 2009) or market capitalization (Sukthomya, 2011) instead. In this study, total asset is used as a proxy for company size.

Jensen and Meckling (1976) suggested that large companies tend to have higher agency costs. Companies of large size are confident of their development prospect, and therefore are willing to communicate with investors in the form of voluntary disclosure, which distinguishes themselves from other companies and increases the value of the company (Li \& Zhao, 2011). The following hypothesis is proposed:

H1a: There is a positive association between company size and the extent of voluntary disclosure.

Profitability and the extent of voluntary disclosure. Empirically, previous studies find a positive association between profitability of the company and the level of voluntary disclosure (Vu, 2012; Nandi \& Ghosh, 2013; Zhang, 2013). A company with high profitability tends to enter the voluntary disclosure with the aim to distinguish themselves from companies with low profitability, to increase the stock price, and to mobilize capital more easily. They want to signal to the investors the company's operating performance (Li \& Zhao, 2011). It is more likely that the management of a profitable enterprise will voluntarily disclose more to the market to enhance the value of the company, as well as the value of their human capital in a competitive labor market (Barako, 2007). Based on the discussion above, the following hypothesis is tested:

$\mathrm{H} 1 \mathrm{~b}$ : There is a positive association between profitability of the company and the extent of voluntary disclosure.

Leverage and the extent of voluntary disclosure. Jensen and Meckling (1976) supposed that agency conflicts are exacerbated by the presence of bondholders in a company's capital structure. It is believed that the higher the level of debt, the higher the level of conflicts of interests among stakeholders (creditors, shareholders, and managers). The creditors try to protect their interests by increasing the interest rate leading to the increase of company agency cost. To gain the creditors' trust, the companies will improve the information transparency by means of voluntary disclosure ( $\mathrm{Li} \&$ Zhao, 2011). Moreover, such companies tend to prepare detailed information to enhance their chance of getting funds from financial institutions (Barako, 2007). Various measures of leverage are used in prior studies such as long-term debt to equity (Sukthomya, 2011; Zhang, 2013), ratio of total debt to total assets of a company (Vu, 2012; Lan et al., 2013; Qu, 2011). This study will use the ratio of total debt to total assets of a company as leverage variable. The following hypothesis is examined:

H1c: There is a positive association between leverage and the extent of voluntary disclosure.

\section{The Relation Between Ownership Structures and the Extent of Voluntary Disclosure}

$\mathrm{Vu}$ (2012) used in her study three different determinants of ownership structure: state ownership, managerial ownership, and foreign ownership. In this study, the same determinants are used. 
State ownership. State ownership is a distinct feature of the Vietnamese stock market. According to International Finance Corporation (IFC, 2010), in Vietnam, the percentage of state-held shares is based on the criteria for classification of state enterprises publicized by the Prime Minister for each period. For enterprises in which the state does not need to hold dominant shares, the equitization agency shall decide on the percentage of state-held shares as appropriate. Therefore, the state can participate in a company either as an ordinary shareholder or as the holder of privileged rights. In Vietnam, state-owned joint stock companies are those which hold more than $51 \%$ of the total equity of a company. Although an increasing number of public companies are owned by non-governmental entities, a majority of listed companies on HSX and HNX remain owned by central or local governments, and state ownership still plays an important role. Apart from Vu (2012), other researchers also examine the role of state ownership in corporate disclosure, including Lan et al. (2013), Qu (2011), Alves et al. (2012), Elmans (2012), Yuen, Liu, Zhang, and Lu (2009), and Zhang (2013). Yuen et al. (2009) found a positive relationship between the extent of state ownership and the level of voluntary disclosure, while Zhang (2013) found the negative one. The following hypothesis will be examined:

H2a: There is a negative association between the extent of state ownership and the level of voluntary disclosure.

Managerial ownership. Managerial ownership can be measured by the proportion of shares held by CEO and executive directors. Using agency theory, it is argued that companies with higher management of ownership structure may disclose less information to shareholders through voluntary disclosure. It is because the determined ownership structure provides companies with lower incentives to voluntarily disclose information to meet the needs of non-dispersed shareholders groups (Rouf \& Harun, 2011). Furthermore, according to Jensen and Meckling (1976), when managerial ownership is low, there is a greater agency cost as the manager has greater incentives to consume perks and reduced incentives to maximize company value. Alves et al. (2012), $\mathrm{Vu}$ (2012), and Rouf (2011) stated in their studies that there was a negative association between the managerial ownership and the level of voluntary disclosure. The hypothesis in this study is as follows:

$\mathrm{H} 2 \mathrm{~b}$ : There is a negative association between the extent of managerial ownership and the level of voluntary disclosure.

Foreign ownership. Foreign ownership is measured by the proportion of shares held by foreign investors. $\mathrm{Vu}$ (2012) studied 252 non-financial Vietnamese listed companies and found that the level of foreign ownership is very low $(9.8 \%)$, and foreign ownership has no impact on voluntary disclosure practice. Several studies investigate the relationship between voluntary disclosure and foreign ownership. Sukthomya (2011) examined SET100 listed companies over the period from 1995 to 2005 and the result indicates that there is a positive association between foreign ownership and the extent of voluntary disclosure. Barako (2007) and Hassan (2013) investigated the positive relationship between voluntary disclosure level and the extent of foreign ownership. Therefore, the hypothesis of this study is that:

$\mathrm{H} 2 \mathrm{c}$ : There is a positive association between the extent of foreign ownership and the level of voluntary disclosure.

\section{The Relation Between the Corporate Governance and the Extent of Voluntary Disclosure}

The corporate governance examined in this study includes board independence, role duality, and type of external auditors. 
Board independence. In this study, board independence refers to the number of non-executive directors to the total number of directors on corporate board. To date, there have been several studies of various researchers around the world on the relation between the board independence and the level of voluntary disclosure. $\mathrm{Vu}$ (2012), Sukthomya (2011), Alves et al. (2012), Nandi and Ghosh (2013), Lan et al. (2013), Al-Janadi et al. (2013), and Qu (2011) revealed that the proportion of independent directors on corporate board is an important aspect associated positively with voluntary disclosure. The hypothesis in this study is proposed as follows:

H3a: There is a positive association between the extent of non-executive directors and the level of voluntary disclosure.

Role duality. Dominant personality exists when the same person serves as a CEO of a company and chairman of the board of directors (Thangatorai, Jaffar, \& Shukor, 2011). Sukthomya (2011), after studied the 1995, 1996, 2002, and 2006 annual reports of Thai listed companies in SET100 Index in the Stock Exchange of Thailand, found in his research that companies with CEO duality tend to have a lower level of voluntary disclosures. Khodadadi, Khazami, and Aflatooni (2010) studied 106 listed companies in Tehran Stock Exchange during 2001-2005 and found no significant relationship between the CEO/chairman duality and the extent of voluntary disclosure. Zaheer (2013) also found no significant association between voluntary disclosure and CEO duality. Al-Janadi et al. (2013) examined the annual reports of 87 listed companies from the Saudi Stock Market and pointed out the positive relation between the separation of the CEO and chairman positions and voluntary disclosure level. Nandi and Ghosh (2013) and Yuen et al. (2009) revealed a positive association between the CEO duality and voluntary disclosure. Based on the above mentioned studies, the hypothesis for this study is as follows:

H3b: There is a positive association between the CEO duality and the level of voluntary disclosure.

Type of external auditors. Agency theory suggests that companies exercise their choice of auditors as a mechanism to reduce the conflicts of interests between shareholders and managers, as auditing facilitates shareholders in the monitoring process (Jensen \& Meckling, 1976). Previous studies have examined the association between the corporate voluntary disclosure and the role of external auditors. $\mathrm{Vu}$ (2012) indicated that there is no significant difference between the overall voluntary disclosures made by companies audited by "Big 4" auditing companies and non-"Big 4" auditing companies. Qu (2011) stated that international audit companies were found to play a positive and significant role in improving disclosure transparency among listed companies. Al-Janadi et al. (2013) found a positive relation between the Big 4 auditing companies and the disclosure of information. Ağca and Önder (2007) revealed that being audited by major international auditing companies has a positive impact on the level of voluntary strategic, financial, non-financial, and total information disclosure. The hypothesis will be formulated as follows:

$\mathrm{H} 3 \mathrm{c}$ : There is a positive association between the Big 4 auditing companies and the level of voluntary disclosure.

\section{Research Methodology}

\section{Sample and Data}

Population and sample collection. To the end of 2012, there were 308 companies listed on HSX and 396 companies listed on HNX. However, due to the time and capability limit, this study will be conducted on the sample of 209 industrial and manufacturing listed companies (111 on HNX and the remaining 98 on HSX). The data will be collected from the 2012 annual reports of those companies publicly available on the company's websites, on the websites of HNX and HSX, or Vietstock (a leading financial analyst's database in Vietnam) 
for analysis. Banks, financial, securities, and insurance companies (as they report under different or specific regulations), companies which are newly listed (after the financial year of December 31, 2012), and companies in other sectors other than industrial and manufacturing are excluded from the sample. The final list of companies in the sample includes 205 companies.

Data collection and data source. The secondary data used for this study are taken from companies' annual reports for the financial year ending December 31, 2012. The annual report is chosen because it is one of the most important sources of company information. Botosan (1997) indicated that although the annual report is not only means of corporate communication, it serves as a good proxy for the level of voluntary disclosure provided by a company across all disclosure avenues. Annual report is the core basis of voluntary non-financial and financial information enlightened by publicly-owned listed companies (Bilal et al., 2013). Additionally, annual report is a mandatory requirement for all public companies in Vietnam.

\section{Dependent and Independent Variables}

Dependent variable. The dependent variable is Vietnamese Voluntary Disclosure Index (ViDI). The level of voluntary disclosure is measured by the number of companies that voluntarily disclose information.

Construction of the voluntary disclosure checklist. The aim of construction of the voluntary disclosure index is to select items of voluntary disclosure that could be presented in the company annual report. There are some alternative approaches of constructing the disclosure index. First, a self-constructed disclosure index could be used to measure the level of corporate information disclosure. Yuen et al. (2009) adopted this approach and constructed their checklist of 51 items after referencing to several important corporate governance principles and recommendations by organizations.

The second approach is one in which the researcher adopts an existing index and makes some modifications to construct an index that is more appropriate for each research context and environment. This approach has been adopted by Vu (2012), Li and Zhao (2011), Qu (2011), Sukthomya (2011), and Hossain and Hammami (2009).

The third approach is a disclosure index developed by another organization such as a rating agency or professional association. For instance, Lokman (2011) utilized the disclosure index developed by the Minority Shareholder Watchdog Group (MSWG) in Malaysia to measure the level of voluntary disclosure of Malaysian publicly listed companies.

The second approach will be used for this study. Following previous studies, an extensive review of prior studies was undertaken to check for commonalities across the studies and to identify the consistency between those disclosure items in this study. Based on various studies to measure the level of disclosure, Vu (2012) has developed ViDI when studying the determinants of voluntary disclosure for Vietnamese listed companies. This list of ViDI includes 84 items. Those 84 items are categorized into five groups: Corporate and Strategic Information; Financial and Capital Market Information; Director and Senior Management Information; Forward Looking Information; and Social Reporting Information. As the study of Vu (2012) has just taken recently, her checklist of Vietnamese Disclosure Index will be used for this study. However, this list will be screened more by excluding the mandatory disclosure requirements released by Circular No. 52/2012/TT-BTC Guidance for Information Disclosure on Stock Exchange; and by considering Vietnam's situation, several items are also excluded and some items are added (based on the study of Li \& Zhao, 2011). The final list of Vietnamese Disclosure Index of 42 items is constructed for this study (see Appendix 1). 
Measuring ViDI. In this study, the unweighted disclosure approach will be used to measure ViDI, because it is documented less subjective and judgmental. A company is given the value of 1 for a disclosed item and 0 if otherwise. ViDI calculated for each company is as follows:

$$
V i D I_{j}=\frac{\Sigma_{t=1} X_{i j}}{n_{i}}
$$

where:

$V i D I_{j}=$ Voluntary disclosure index for $j^{\text {th }}$ company;

$n_{i}=$ Voluntary disclosure item applicable to $j^{\text {th }}$ company $(n \leq 42$ items);

$X_{i j}=1$ if the item $i$ of company $j$ is disclosed, and 0 if otherwise.

The use of the above formula has been employed by some researchers such as Vu (2012), Sukthomya (2011), and Hossain and Hammami (2009).

Independent variables. The key independent variables examined in this study include: company size, profitability, leverage (company characteristics), state ownership, managerial ownership, foreign ownership (ownership structure), board independence, role duality, and type of external auditors (corporate governance).

\section{Results and Discussion}

\section{Descriptive Statistic Results}

ViDI and its four sub-categories. Table 1 below presents the descriptive statistic results of ViDI and its four sub-categories. The data are taken from the annual reports of 205 Vietnamese industrial and manufacturing listed companies in the year 2012. As shown in Table 1, the overall ViDI is at $32.16 \%$, and the standard deviation is $17.94 \%$.

Table 1

Descriptive Statistics Results of ViDI and Four Sub-categories

\begin{tabular}{lllll}
\hline Category & Minimum & Maximum & Mean (\%) & Std. deviation \\
\hline VDCS (Corporate and Strategic Information: 11 items) & 0.00 & 1.00 & 41.06 & 0.24480 \\
VDFC (Vietnamese Financial and Capital Market & 0.00 & 0.86 & 25.44 & 0.18049 \\
Information: 14 items) & & & & \\
VDFL (Forward Looking Information: 8 items) & 0.00 & 0.88 & 20.00 & 0.23698 \\
VDSI (Social Reporting Information: 9 items) & 0.00 & 1.00 & 42.55 & 0.23737 \\
ViDI (Vietnamese Disclosure Index) & 0.02 & 0.81 & 32.16 & 0.17944 \\
\hline
\end{tabular}

As shown in Table 1 above, the sub-category of Social Reporting Information has the highest level of communication (a mean of $42.55 \%$ ), while Forward Looking Information has the lowest disclosure at $20.00 \%$. Corporate and Strategic Information comes second with $41.06 \%$, and Financial and Capital Market Information ranked third with $25.44 \%$.

Descriptive results for independent variables. It is shown in Table 2 that the total asset measurement of 205 industrial and manufacturing listed companies is highly skewed; and the alternative is to use natural log of total assets to measure the company's size. The companies in the sample have an average return on assets of $5.34 \%$ and an average leverage ratio of $52.78 \%$. It is also shown that the mean of proportion of non-executive independent directors on corporate board is $47.40 \%$; that means most of companies in the sample meet the required one third of non-executive independent directors on corporate boards. However, there are 50 companies 
that do not satisfy the above-mentioned requirement. The results indicate that the companies audited by Big 4 auditing firms are averaged at $20.98 \%$, while $41.95 \%$ of companies in the sample have a CEO performing as a corporate chairman.

Table 2

Descriptive Statistics Results of Independent Variables

\begin{tabular}{llclcl}
\hline Variable & $N$ & Minimum (\%) & Maximum (\%) & Mean (\%) & Std. deviation \\
\hline SIZE (Logarithm of total assets) & 205 & 2.32 & 31.44 & 26.94 & 1.41 \\
PROFIT (Profitability) & 205 & -33.04 & 33.00 & 0.053 & 0.089 \\
LEV (Leverage) & 205 & 3.90 & 93.10 & 0.53 & 0.22 \\
STATE (State ownership) & 205 & 0 & 96.72 & 0.23 & 0.25 \\
MAN (Managerial ownership) & 205 & 0 & 61.14 & 17.57 & 0.18 \\
FOREIGN (Foreign ownership) & 205 & 0 & 49.00 & 7.99 & 0.13 \\
CG (Board independence) & 205 & 0 & 1 & 47.40 & 0.21 \\
CEO (Role duality) & 205 & 0 & 1 & 41.95 & 0.49 \\
AUDIT (Type of external auditors) & 205 & 0 & 1 & 20.98 & 0.41 \\
\hline
\end{tabular}

Table 3

Spearman and Pearson Correlation Matrix

\begin{tabular}{|c|c|c|c|c|c|c|c|c|c|c|c|}
\hline Variable & & $V i D I$ & SIZE & PROFIT & $L E V$ & STATE & $M A N$ & FOREIGN & $C G$ & CEO & $A U D I T$ \\
\hline \multirow[t]{2}{*}{$V i D I$} & $\begin{array}{l}\text { Pearson } \\
\text { correlation }\end{array}$ & 1 & $0.327^{* *}$ & $0.187^{* *}$ & 0.004 & -0.008 & 0.042 & $0.289^{* *}$ & 0.060 & $-0.128^{*}$ & $0.233^{* *}$ \\
\hline & Sig. (1-tailed) & & 0.000 & 0.004 & 0.476 & 0.453 & 0.275 & 0.000 & 0.195 & 0.033 & 0.000 \\
\hline \multirow[t]{2}{*}{ SIZE } & $\begin{array}{l}\text { Pearson } \\
\text { correlation }\end{array}$ & $0.327^{* *}$ & 1 & $0.199^{* *}$ & $0.166^{* *}$ & 0.047 & -0.071 & $0.363^{* *}$ & $0.169^{* *}$ & $-0.139^{*}$ & $0.463^{* *}$ \\
\hline & Sig. (1-tailed) & 0.000 & & 0.002 & 0.009 & 0.251 & 0.157 & 0.000 & 0.008 & 0.023 & 0.000 \\
\hline \multirow[t]{2}{*}{ PROFIT } & $\begin{array}{l}\text { Pearson } \\
\text { correlation }\end{array}$ & $0.187^{* *}$ & $0.199^{* *}$ & 1 & $-0.374^{* *}$ & $0.164^{* *}$ & -0.083 & $0.258^{* *}$ & $0.143^{*}$ & -0.080 & $0.213^{* *}$ \\
\hline & Sig. (1-tailed) & 0.004 & 0.002 & & 0.000 & 0.010 & 0.119 & 0.000 & 0.021 & 0.128 & 0.001 \\
\hline \multirow[t]{2}{*}{$L E V$} & $\begin{array}{l}\text { Pearson } \\
\text { correlation }\end{array}$ & 0.004 & $0.166^{* *}$ & $-0.374^{* *}$ & 1 & -0.027 & 0.092 & $-0.235^{* *}$ & $-0.192^{* *}$ & 0.034 & -0.029 \\
\hline & Sig. (1-tailed) & 0.476 & 0.009 & 0.000 & & 0.352 & 0.095 & 0.000 & 0.003 & 0.313 & 0.341 \\
\hline \multirow[t]{2}{*}{ STATE } & $\begin{array}{l}\text { Pearson } \\
\text { correlation }\end{array}$ & -0.008 & 0.047 & $0.164^{* *}$ & -0.027 & 1 & $-0.375^{* *}$ & -0.109 & -0.095 & $-0.143^{*}$ & -0.041 \\
\hline & Sig. (1-tailed) & 0.453 & 0.251 & 0.010 & 0.352 & & 0.000 & 0.060 & 0.087 & 0.020 & 0.282 \\
\hline \multirow[t]{2}{*}{$M A N$} & $\begin{array}{l}\text { Pearson } \\
\text { correlation }\end{array}$ & 0.042 & -0.071 & -0.083 & 0.092 & $-0.375^{* *}$ & 1 & -0.070 & 0.002 & $0.145^{*}$ & -0.105 \\
\hline & Sig. (1-tailed) & 0.275 & 0.157 & 0.119 & 0.095 & 0.000 & & 0.160 & 0.489 & 0.019 & 0.066 \\
\hline \multirow[t]{2}{*}{ FOREIGN } & $\begin{array}{l}\text { Pearson } \\
\text { correlation }\end{array}$ & $0.289^{* *}$ & $0.363^{* *}$ & $0.258^{* *}$ & $-0.235^{* *}$ & -0.109 & -0.070 & 1 & 0.045 & -0.079 & $0.449^{* *}$ \\
\hline & Sig. (1-tailed) & 0.000 & 0.000 & 0.000 & 0.000 & 0.060 & 0.160 & & 0.259 & 0.129 & 0.000 \\
\hline \multirow[t]{2}{*}{$C G$} & $\begin{array}{l}\text { Pearson } \\
\text { correlation }\end{array}$ & 0.060 & $0.169^{* *}$ & $0.143^{*}$ & $-0.192^{* *}$ & -0.095 & 0.002 & 0.045 & 1 & $-0.228^{* *}$ & $0.122^{*}$ \\
\hline & Sig. (1-tailed) & 0.195 & 0.008 & 0.021 & 0.003 & 0.087 & 0.489 & 0.259 & & 0.000 & 0.040 \\
\hline \multirow[t]{2}{*}{$C E O$} & $\begin{array}{l}\text { Pearson } \\
\text { correlation }\end{array}$ & $-0.128^{*}$ & $-0.139^{*}$ & -0.080 & 0.034 & $-0.143^{*}$ & $0.145^{*}$ & -0.079 & $-0.228^{* *}$ & 1 & $-0.147^{*}$ \\
\hline & Sig. (1-tailed) & 0.033 & 0.023 & 0.128 & 0.313 & 0.020 & 0.019 & 0.129 & 0.000 & & 0.018 \\
\hline \multirow[t]{2}{*}{$A U D I T$} & $\begin{array}{l}\text { Pearson } \\
\text { correlation }\end{array}$ & $0.233^{* *}$ & $0.463^{* *}$ & $0.213^{* *}$ & -0.029 & -0.041 & -0.105 & $0.449^{* *}$ & $0.122^{*}$ & $-0.147^{*}$ & 1 \\
\hline & Sig. (1-tailed) & 0.000 & 0.000 & 0.001 & 0.341 & 0.282 & 0.066 & 0.000 & 0.040 & 0.018 & \\
\hline
\end{tabular}

Notes. ": Correlation is significant at the 0.05 level (1-tailed); ${ }^{* * *}$ : Correlation is significant at the 0.01 level (1-tailed). Number of companies: 205. 
Table 4

Collinearity Statistics

\begin{tabular}{llc}
\hline \multirow{2}{*}{ Variable } & \multicolumn{2}{c}{ Collinearity statistic } \\
\cline { 2 - 3 } & Tolerance & VIF \\
\hline SIZE (Logarithm of total assets) & 0.644 & 1.552 \\
PROFIT (Profitability) & 0.753 & 1.328 \\
LEV (Leverage) & 0.702 & 1.424 \\
STATE (State ownership) & 0.775 & 1.290 \\
MAN (Managerial ownership) & 0.829 & 1.206 \\
FOREIGN (Foreign ownership) & 0.666 & 1.500 \\
CG (Board independence) & 0.847 & 1.181 \\
CEO (Role duality) & 0.897 & 1.115 \\
AUDIT (Type of external auditors) & 0.678 & 1.475 \\
\hline NOte. Dep & &
\end{tabular}

Note. Dependent variable: ViDI (Vietnamese Disclosure Index).

It is reported in Table 2 that the proportion of foreign ownership of Vietnamese industrial and manufacturing listed companies is averaged at $7.99 \%$. This proportion ranges from $0 \%$ to $49 \%$ (the maximum ceiling of foreign ownership specified by the law).

In terms of managerial ownership, it is averaged at $17.57 \%$; and the highest managerial ownership is $61.14 \%$.

The Pearson correlation values in Table 3 above indicate that multicollinearity problems between dependent variable and independent variables are not likely to happen.

As indicated in Table 4 above, tolerance scores are all greater than 0.2 and the VIF for each predictor variable is below the 10.0 benchmark. According to results of the correlation matrices in Tables 3 and 4, it can be seen that multicollinearity does not seem to be a problem in explaining the regression results of ViDI model.

\section{Multivariate Statistic Results}

Assumptions in multiple regression analysis. An important part in using multiple regression analysis is that the assumptions are not violated. These assumptions include multicollinearity issues, outlier issues, homoscedasticity, normality, and linearity.

Outlier issues. To identify the possibility of outliers in the Vietnamese Disclosure Index model, Cook's distance and Mahalanobis distance scores are calculated. Table 5 below describes the residuals statistics.

Table 5

Residuals Statistics

\begin{tabular}{|c|c|c|c|c|c|}
\hline Descriptive statistic & Minimum & Maximum & Mean & Std. deviation & $N$ \\
\hline Predicted value & 0.1623 & 0.5599 & 0.3216 & 0.07272 & 205 \\
\hline Std. predicted value & -2.191 & 3.277 & 0.000 & 1.000 & 205 \\
\hline Standard error of predicted value & 0.023 & 0.066 & 0.036 & 0.008 & 205 \\
\hline Adjusted predicted value & 0.1597 & 0.5819 & 0.3219 & 0.07380 & 205 \\
\hline Residual & -0.29409 & 0.45038 & 0.00000 & 0.16405 & 205 \\
\hline Std. residual & -1.753 & 2.684 & 0.000 & 0.978 & 205 \\
\hline Stud. residual & -1.826 & 2.725 & -0.001 & 1.005 & 205 \\
\hline Deleted residual & -0.31921 & 0.46415 & -0.00030 & 0.17328 & 205 \\
\hline Stud. deleted residual & -1.837 & 2.771 & 0.001 & 1.010 & 205 \\
\hline Mahal. distance & 2.753 & 30.950 & 8.956 & 4.881 & 205 \\
\hline Cook's distance & 0.000 & 0.058 & 0.006 & 0.009 & 205 \\
\hline Centered leverage value & 0.013 & 0.152 & 0.044 & 0.024 & 205 \\
\hline
\end{tabular}

Note. Dependent variable: ViDI (Vietnamese Disclosure Index). 
It is presented in Table 5 above that the maximum score of Cook's distance for the 205 companies is 0.058 , which is below the benchmark of 1.0. It is likely to be concluded that there is no multivariate outlier in the data set of 205 sample companies.

The Mahalanobis score tests were conducted and the results suggest that there are two outliers in the data set with Mahalanobis scores of 29.23 and 30.95 respectively.

Table 6 (a) and Table 6 (b) below compare the results between the two data sets (with and without the removal of the two outliers), and it is revealed that there is no major difference in these results.

Table 6 (a)

Multiple Regression Results (Full Data Set)

\begin{tabular}{|c|c|c|c|c|c|c|}
\hline \multirow{2}{*}{\multicolumn{2}{|c|}{ Model }} & \multicolumn{2}{|c|}{ Unstandardized coefficient } & \multirow{2}{*}{$\begin{array}{l}\text { Standardized } \\
\text { coefficient } \\
\text { Beta }\end{array}$} & \multirow[t]{2}{*}{$t$} & \multirow{2}{*}{ Sig. } \\
\hline & & $\mathrm{B}$ & Std. error & & & \\
\hline \multirow{10}{*}{1} & (Constant) & -0.467 & 0.263 & & -1.777 & 0.077 \\
\hline & SIZE (Logarithm of total assets) & 0.027 & 0.010 & 0.215 & 2.633 & 0.009 \\
\hline & PROFIT (Profitability) & 0.218 & 0.151 & 0.109 & 1.448 & 0.149 \\
\hline & $L E V$ (Leverage) & 0.036 & 0.063 & 0.044 & 0.567 & 0.571 \\
\hline & STATE (State ownership) & 0.005 & 0.054 & 0.007 & 0.092 & 0.927 \\
\hline & MAN (Managerial ownership) & 0.094 & 0.073 & 0.093 & 1.298 & 0.196 \\
\hline & FOREIGN (Foreign ownership) & 0.243 & 0.108 & 0.181 & 2.251 & 0.025 \\
\hline & $C G$ (Board independence) & -0.013 & 0.062 & -0.015 & -0.205 & 0.838 \\
\hline & $C E O$ (Role duality) & -0.032 & 0.025 & -0.089 & -1.280 & 0.202 \\
\hline & AUDIT (Type of external auditors) & 0.013 & 0.035 & 0.029 & 0.369 & 0.712 \\
\hline
\end{tabular}

Notes. Dependent variable: ViDI (Vietnamese Disclosure Index). Adjusted $R=0.125 ; F=4.251$; Sig. $=0.000 ; N=205$.

Table 6 (b)

Multiple Regression Results (Removing Outliers)

\begin{tabular}{|c|c|c|c|c|c|c|}
\hline \multirow{2}{*}{\multicolumn{2}{|c|}{ Model }} & \multicolumn{2}{|c|}{ Unstandardized coefficient } & \multirow{2}{*}{$\begin{array}{l}\text { Standardized } \\
\text { coefficient } \\
\text { Beta }\end{array}$} & \multirow[t]{2}{*}{$t$} & \multirow[t]{2}{*}{ Sig. } \\
\hline & & $\mathrm{B}$ & Std. error & & & \\
\hline \multirow{10}{*}{1} & (Constant) & -0.587 & 0.275 & & -2.132 & 0.034 \\
\hline & SIZE (Logarithm of total assets) & 0.032 & 0.011 & 0.247 & 2.957 & 0.003 \\
\hline & PROFIT (Profitability) & 0.177 & 0.161 & 0.085 & 1.097 & 0.274 \\
\hline & $L E V$ (Leverage) & 0.019 & 0.065 & 0.024 & 0.292 & 0.770 \\
\hline & STATE (State ownership) & 0.008 & 0.054 & 0.011 & 0.148 & 0.883 \\
\hline & MAN (Managerial ownership) & 0.093 & 0.073 & 0.093 & 1.286 & 0.200 \\
\hline & FOREIGN (Foreign ownership) & 0.246 & 0.108 & 0.183 & 2.277 & 0.024 \\
\hline & $C G$ (Board independence) & 0.000 & 0.062 & 0.000 & 0.002 & 0.998 \\
\hline & $C E O$ (Role duality) & -0.029 & 0.025 & -0.080 & -1.150 & 0.252 \\
\hline & AUDIT (Type of external auditors) & 0.000 & 0.036 & 0.000 & -0.005 & 0.996 \\
\hline
\end{tabular}

Notes. Dependent variable: ViDI (Vietnamese Voluntary Disclosure Index). Adjusted $R=0.126 ; F=4.238 ;$ Sig. $=0.000 ; N=205$.

Normality. The descriptive results of the sample data show that the value for skewness of the data is 0.764 , while the value for kurtosis is 0.012 , which are both very close to the normal distribution requirements. Furthermore, Figure 1 below shows the histogram of the dependent variable (ViDI) that looks like a bell-shaped curve, which seems to be a normal distribution. Figure 2 shows normal probability plots with the points for the cases line up along the diagonal. Taken together, the normality assumption of the regression analysis is likely to be met. 


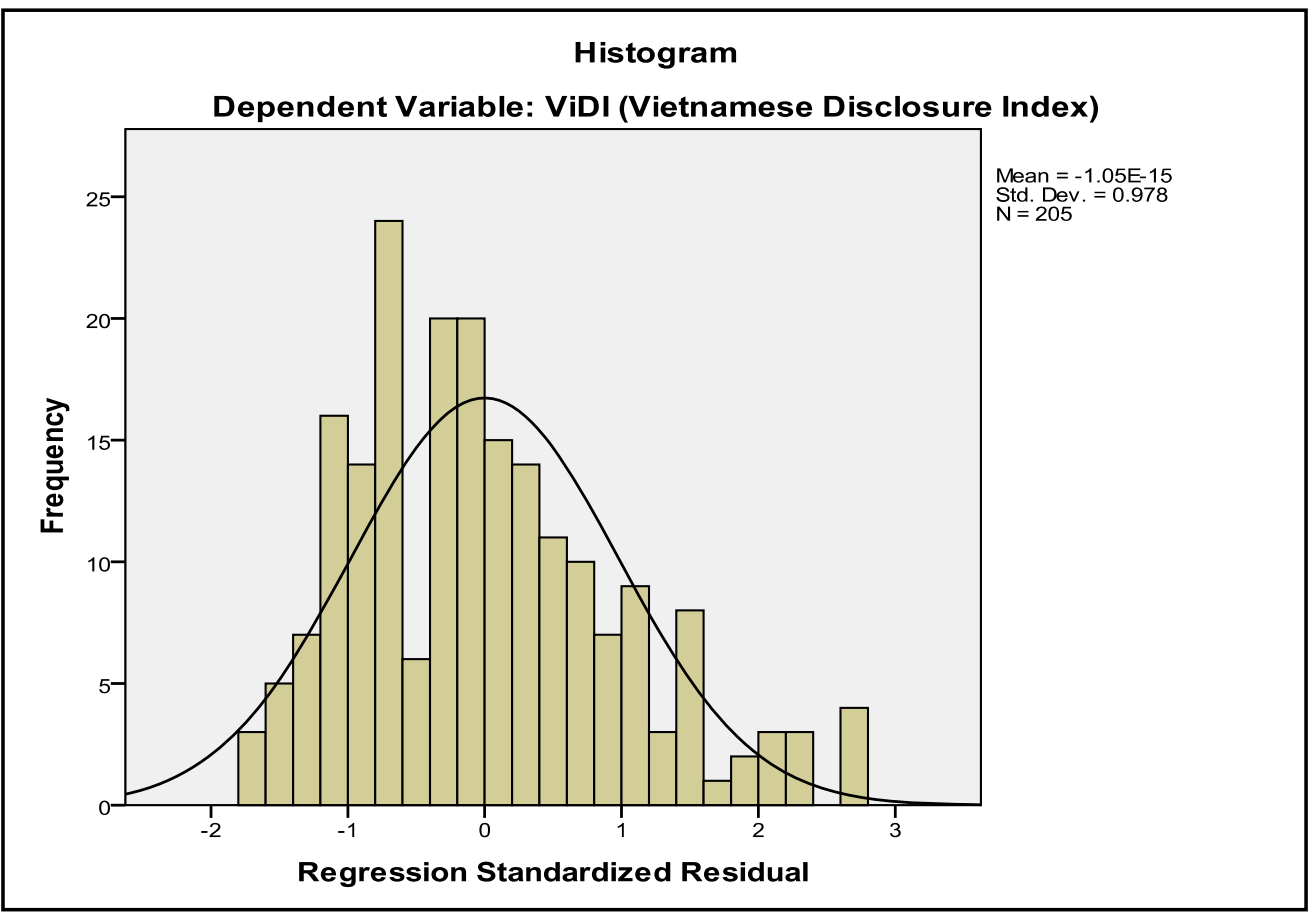

Figure 1. Histogram of Vietnamese Disclosure Index.

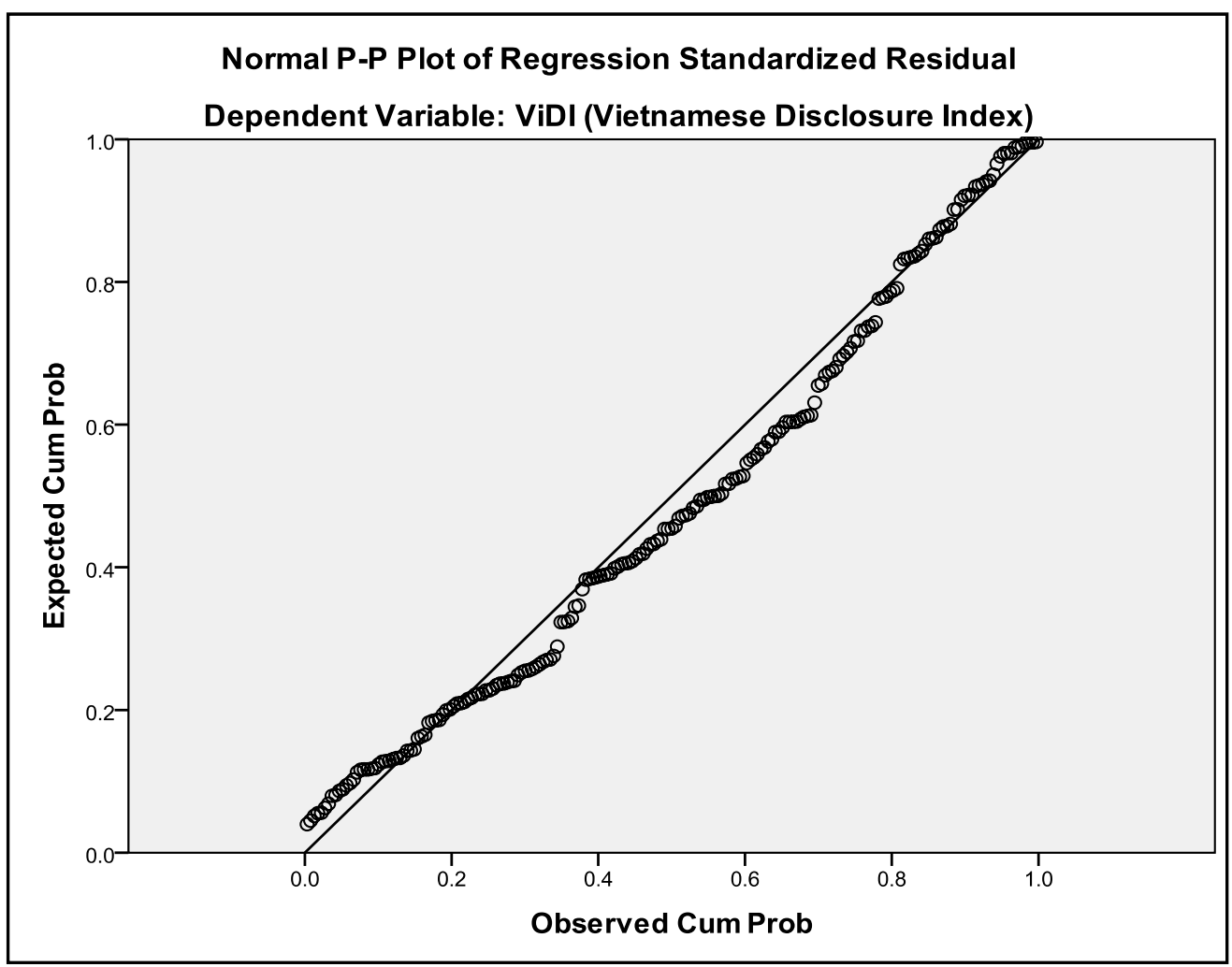

Figure 2. P-P plot of Vietnamese Disclosure Index.

Linearity and homoscedasticity. Figure 3 below shows a clear linear relationship between the residuals and the predicted values. Thus, the overall regression model in this study is likely to be linear and homoscedastic. 


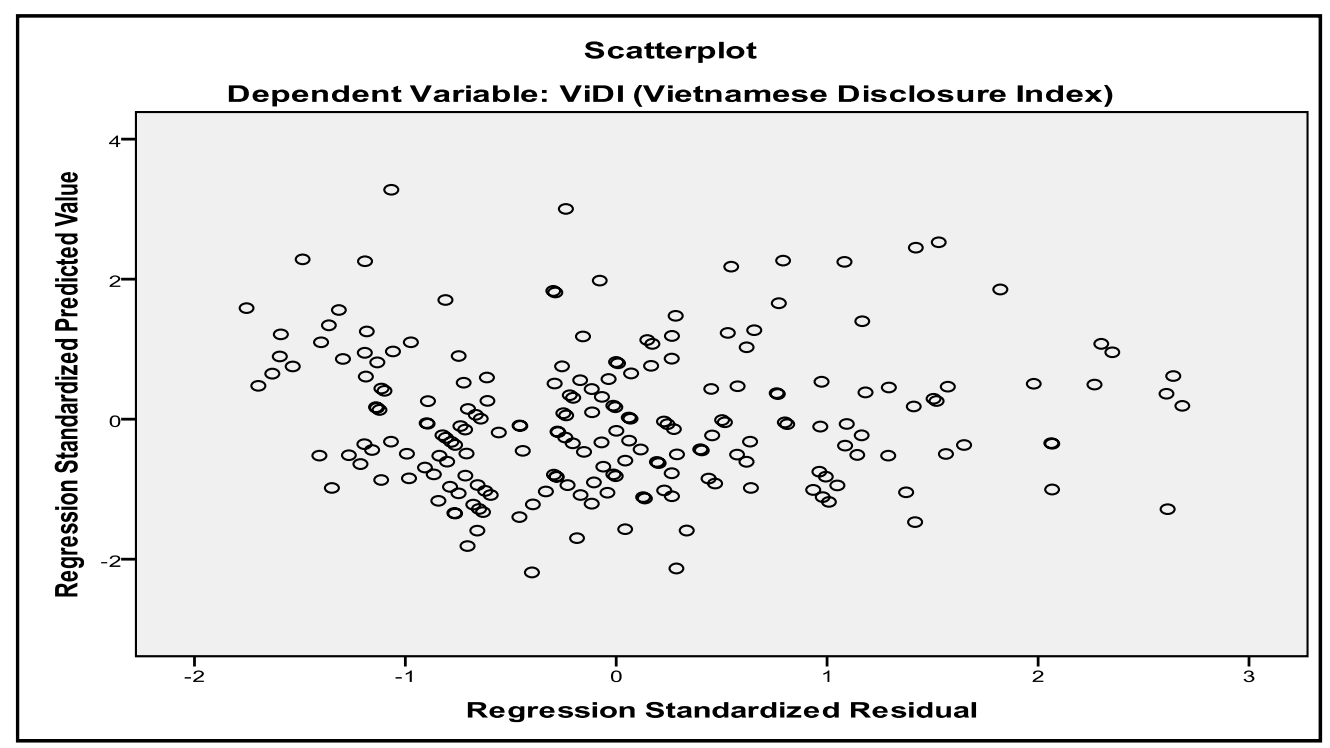

Figure 3. Scatterplot of ViDI.

Multiple regression results. The regression model of this study is as follows:

$$
\begin{aligned}
V_{i D I_{i}=} & \beta_{0}+\beta_{1} \text { SIZE }_{J}+\beta_{2} \text { PROFIT }_{J}+\beta_{3} \text { LEV }_{J}+\beta_{4} \text { STATE }_{J}+\beta_{5} M A N_{J} \\
& +\beta_{6} \text { FOREIGN }_{J}+\beta_{7} C G_{J}+\beta_{8} C E O_{J}+\beta_{9} \text { AUDIT }_{J}+\varepsilon_{i}
\end{aligned}
$$

where:

$V i D I_{i}=$ Ratio of Vietnamese voluntary disclosure items reported by company $j$ in the 2012 annual report;

$S I Z E_{J}=$ Logarithm total assets of company $j$ as reported;

PROFIT $_{J}=$ Ratio of net profit to total asset of company $j$ as reported;

$L E V_{J}=$ Ratio of total debt to total asset of company $j$ as reported;

$S T A T E_{J}=$ Number of ordinary outstanding shares held by the Vietnamese Government in company $j$ divided by the total number of ordinary outstanding shares of company $j$ at the cut-off date specified in the 2012 annual report of company $j$;

$M A N_{J}=$ Number of ordinary outstanding shares held by senior managers on corporate board in company $j$ divided by the total number of ordinary outstanding shares of company $j$ at the cut-off date specified in the 2012 annual report of company $j$;

$F O R E I G N_{J}=$ Number of ordinary outstanding shares held by foreign owners in company $j$ divided by the total number of ordinary outstanding shares of company $j$ at the cut-off date specified in the 2012 annual report of company $j$;

$C G_{J}=$ Number of non-executive directors stated in the 2012 annual report of company $j$ divided by the total number of all directors in the 2012 annual report of company $j$;

$C E O_{J}=$ Value of 1 is given if the chief executive manager is also chairperson of the board and 0 if otherwise; $A U D I T_{J}=$ Value of 1 is given if the company $j$ is audited by Big 4 auditing company and 0 if otherwise;

$\beta_{0}=$ Regression constant;

$\beta_{1,2, \ldots, n}=$ Coefficient to independent variables;

$\varepsilon_{i}=$ Error of prediction.

The regression results are presented in Table 7 below. 
Table 7

Multiple Regression Results

\begin{tabular}{|c|c|c|c|}
\hline \multicolumn{4}{|l|}{ Model summary } \\
\hline$R$ & $0.405^{\mathrm{a}}$ & & \\
\hline$R$-square & 0.164 & & \\
\hline Adjusted $R$-square & 0.126 & & \\
\hline Std. error of the estimate & 0.16781 & & \\
\hline Sig. & 0.000 & & \\
\hline$F$ & 4.258 & & \\
\hline Variable & Coefficient & $t$-statistic & Sig. \\
\hline (Constant) & -0.467 & -1.777 & 0.077 \\
\hline SIZE (Logarithm of total assets) & 0.027 & 2.633 & $0.009^{* *}$ \\
\hline PROFIT (Profitability) & 0.218 & 1.448 & 0.149 \\
\hline LEV (Leverage) & 0.036 & 0.567 & 0.571 \\
\hline STATE (State ownership) & 0.005 & 0.092 & 0.927 \\
\hline MAN (Managerial ownership) & 0.094 & 1.298 & 0.196 \\
\hline FOREIGN (Foreign ownership) & 0.243 & 2.251 & $0.025^{* *}$ \\
\hline$C G$ (Board independence) & -0.013 & -0.205 & 0.838 \\
\hline$C E O$ (Role duality) & -0.032 & -1.280 & 0.202 \\
\hline AUDIT (Type of external auditors) & 0.013 & 0.369 & 0.712 \\
\hline
\end{tabular}

Notes. Legend: Shaded areas describe statistically significant findings. ": Correlation is highly significant at the 0.01 level;

${ }^{* *}:$ Correlation is significant at the 0.05 level; ${ }^{* * *}$ : Correlation is moderately significant at the 0.1 level. ViDI $=$ Vietnamese Voluntary Disclosure Index. Number of companies $=205$. $^{\text {a }}$ : Predictors: (Constant), AUDIT, LEV, STATE, CEO, CG, MAN, PROFIT, FOREIGN, and SIZE.

As shown in Table 7 above, the model is significant $(F=4.258, p$-value $=0.000)$ with the adjusted coefficient of determination (adjusted $R$-square) is 0.126 , indicating that the predictor variables of the model explain $12.6 \%$ of the variation in the Vietnamese Disclosure Index (ViDI). The regression coefficient for SIZE $(\beta=0.027)$ is positive and statistically significant ( $p$-value $=0.009)$, suggesting that bigger companies are associated with more voluntary disclosure of information. This provides a support for H1a that there is a positive association between the size of a company and the extent of voluntary disclosure made by Vietnamese listed companies. This finding is consistent with the findings of other researchers such as Qu (2011), Hossain and Hammami (2009), Sukthomya (2011), and Vu (2012).

The results also reveal that the foreign ownership has a positive and statistically significant influence on the level of voluntary disclosure $(\beta=0.243, p$-value $=0.025)$. Thus, $\mathrm{H} 2 \mathrm{c}$ that there is a positive association between the extent of foreign ownership and the level of voluntary disclosure is also supported. This implies that the company with a higher proportion of ordinary outstanding shares held by foreign shareholders engages in more information disclosure practice.

However, other independent variables such as profitability, leverage, state ownership, managerial ownership, board independence, role duality, and type of external auditors are not statistically significant in explaining the voluntary disclosure practice made by Vietnamese industrial and manufacturing listed companies. Although the directions are predicted, the results shown in Table 7 do not present any significant relationship. Therefore, H1b, $\mathrm{H} 1 \mathrm{c}, \mathrm{H} 2 \mathrm{a}, \mathrm{H} 2 \mathrm{~b}, \mathrm{H} 3 \mathrm{a}, \mathrm{H} 3 \mathrm{~b}$, and H3c are not supported.

Multivariate analysis of four sub-categories of disclosure. The aim of this part is to take a deeper analysis of the different types of voluntary disclosure of information made by Vietnamese industrial and 
manufacturing listed companies. The Ordinary Least Square (OLS) regression is used to examine the potential factors that affect a company's disclosure within the four sub-categories that make up the overall ViDI.

Table 8

Multiple Regression Results for Four Sub-categories

\begin{tabular}{|c|c|c|c|c|c|c|c|c|c|c|c|c|}
\hline & VDCS & & & VDFC & & & VDFL & & & VDSI & & \\
\hline Adjusted $R^{2}$ & 0.092 & & & 0.079 & & & 0.019 & & & 0.188 & & \\
\hline$F$-statistics & 3.295 & & & 2.932 & & & 1.445 & & & 6.244 & & \\
\hline Significance & 0.01 & & & 0.03 & & & 0.171 & & & 0.000 & & \\
\hline Sample size & 205 & & & 205 & & & 205 & & & 205 & & \\
\hline \multirow{2}{*}{ Constant } & Coeff. & $t$-stat. & Sig. & Coeff. & $t$-stat. & Sig. & Coeff. & $t$-stat. & Sig. & Coeff. & $t$-stat. & Sig. \\
\hline & -0.650 & -1.779 & 0.077 & -0.400 & -1.473 & 0.142 & -0.695 & -1.891 & 0.060 & -0.140 & -0.418 & 0.677 \\
\hline \multicolumn{13}{|c|}{ Independent variables } \\
\hline$\overline{S I Z E}$ & 0.037 & 2.591 & $0.010^{*}$ & 0.022 & 2.060 & $0.041^{* *}$ & 0.034 & 2.307 & $0.022^{* *}$ & 0.018 & 1.321 & 0.188 \\
\hline PROFIT & 0.275 & 1.311 & 0.191 & 0.101 & 0.647 & 0.519 & -0.062 & -0.293 & 0.770 & 0.581 & 3.020 & $0.003^{* *}$ \\
\hline$L E V$ & 0.002 & 0.020 & 0.984 & 0.052 & 0.797 & 0.426 & 0.003 & 0.034 & 0.973 & 0.083 & 1.029 & 0.305 \\
\hline STATE & 0.047 & 0.625 & 0.533 & -0.012 & -0.219 & 0.827 & -0.049 & -0.639 & 0.523 & 0.028 & 0.408 & 0.684 \\
\hline$M A N$ & 0.118 & 1.170 & 0.243 & 0.120 & 1.596 & 0.112 & -0.043 & -0.425 & 0.671 & 0.147 & 1.593 & 0.113 \\
\hline FOREIGN & 0.308 & 2.053 & $0.041^{* *}$ & 0.319 & 2.856 & $0.005^{* *}$ & -0.061 & -0.404 & 0.687 & 0.323 & 2.346 & $0.020^{* *}$ \\
\hline$C G$ & -0.032 & -0.378 & 0.706 & -0.018 & -0.280 & 0.780 & 0.041 & 0.477 & 0.634 & -0.028 & -0.355 & 0.723 \\
\hline CEO & -0.014 & -0.397 & 0.691 & -0.011 & -0.443 & 0.658 & -0.026 & -0.736 & 0.462 & -0.092 & -2.883 & $0.004^{* *}$ \\
\hline$A U D I T$ & 0.003 & 0.055 & 0.956 & -0.023 & -0.639 & 0.524 & 0.037 & 0.757 & 0.450 & 0.059 & 1.335 & 0.183 \\
\hline
\end{tabular}

Notes. Legend: Sig. = Significant level. ${ }^{*}$ : Correlation is highly significant at the 0.01 level (2-tailed); $;$ : Correlation is significant at the 0.05 level (2-tailed); ${ }^{* * *}$ : Correlation is moderately significant at the 0.1 level (2-tailed). Shaded areas describe statistically significant findings.

Corporate and Strategic Information Index (VDCS). Table 8 indicates that the average voluntary disclosure level of this category is $41.06 \%$. As shown in Table 8 above, the adjusted $R$-square is 0.092 . This means that the model explains about $9.2 \%$ of the variations in voluntary disclosure for this sub-category. The results in Table 8 show that the size of a company is highly significantly and positively associated with the level of voluntary disclosure of this sub-category $(p$-value $=0.010)$. Foreign ownership also has a positive and significant association with the level of voluntary disclosure of corporate and strategic information $(p$-value $=0.041)$. The findings support the idea that big companies are more voluntary in disclosing information than small ones; and foreign investors are likely to actively engage in voluntary disclosure practice of Vietnamese listed companies in the sample. However, other remaining predictor variables, namely, profitability, leverage, state ownership, managerial ownership, corporate governance, role duality, and type of external auditors, have no significant association with the level of voluntary disclosure of this sub-category.

Financial and Capital Market Information Index (VDFC). This sub-category consists of 14 items providing the financial information of the company. As illustrated in Table 8 , the average of voluntary disclosure of this type of information is $25.44 \%$. The model is highly significant at $p$-value $=0.03$ and $F$-statistics $=2.932$. In Table 8 above, the adjusted $R$-square is 0.079 revealing that the model explains $7.9 \%$ of the variations in the voluntary disclosure of this type of information. Company size and foreign ownership are significantly and positively related to the extent of voluntary disclosure of financial and capital market information. Other independent variables (profitability, leverage, state ownership, managerial ownership, corporate governance, role duality, and type of external auditors) have no significant association with the voluntary disclosure of this sub-category. 
Forward Looking Information Index (VDFL). Forward Looking Information sub-category consists of eight items providing the information regarding the business plan of the company. This sub-category has a mean of voluntary disclosure level of $20 \%$, the lowest level as compared with other sub-categories of voluntary disclosure. However, it is shown in Table 8 that the model is not statistically significant ( $p$-value $=0.171, F$-statistics $=1.445$ ).

Social Reporting Information Index (VDSI). Social Reporting Information Index consists of nine items and has an average of voluntary disclosure level of $42.55 \%$, the highest score in the ViDI sub-categories. The model is highly significant with $p$-value $=0.000$ and $F$-statistics $=6.244$. As indicated in Table 8 , profitability and foreign ownership have highly significant and positive associations with the level of VDSI ( $p$-value $=0.003$ and $p$-value $=0.020$, respectively). Role duality is highly significantly and negatively associated with the level of VDSI ( $p$-value $=0.004)$. Although size of the company is found to have a significant relationship with the level of overall ViDI and other sub-categories VDCS, VDFC, and VDFL, no significant association is shown in this model ( $p$-value $=0.188)$. Other predictors (leverage, state ownership, managerial ownership, corporate governance, and type of external auditors) have no significant association with voluntary disclosure of this sub-category.

\section{Conclusion and Future Research Direction}

The voluntary disclosure scores reveal that the level of information disclosure released by Vietnamese industrial and manufacturing companies is low. The study finds that two factors (namely, the company's size and foreign ownership) have a statistically significant and positive influence on the level of voluntary disclosure. A big company engages more in disclosure practice, and foreign ownership seems to play an active role in improving the information disclosure environment of Vietnamese companies in the sample.

One limitation of this study is that the results are based on industrial and manufacturing listed companies, which represent only $29.12 \%$ of the total population at the year end of 2012. Furthermore, the study is limited to a period of one year that may raise further uncertainty about the generalization of the results. Another limitation is that it utilizes only voluntary information disclosed in the annual reports. As mentioned earlier, there are a number of other channels that a company may use to disclose their information such as company's website, stock exchange's website, brochures, press releases, conference meetings, or letters to stakeholders.

In order to overcome those limitations, the dimension of the sample could be increased by analyzing more non-financial Vietnamese listed companies for a longer period of time which may help to validate this study; or other channels of information would be included as a source of data. The two independent variables, such as corporate governance and board composition, can be considered in further studies.

\section{References}

Ağca, A., \& Őnder, S. (2007). Voluntary disclosure in Turkey: A study on firms listed in Istanbul Stock Exchange (ISE). Problems and Perspectives in Management, 5(3), 241-251.

Al-Janadi, Y., Rahman, R. A., \& Omar, N. H. (2013). Corporate governance mechanisms and voluntary disclosure in Saudi Arabia. Research Journal of Finance and Accounting, 4(4), 25-35.

Alves, H., Rodrigues, A. M., \& Canadas, N. (2012). Factors influencing the different categories of voluntary disclosure in annual reports: An analysis for Iberian Peninsula listed companies. Tekhne Review of Applied Management Studies, 10(1), 15-26.

Barako, D. G. (2007). Determinants of voluntary disclosures in Kenyan companies annual reports. African Journal of Business Management, 1(5), 113-128.

Bilal, Tufail, S., Khan, J., Abbas, A., \& Saeed, A. (2013). The association between firm-specificcharacteristics and corporate disclosure: Evidence from pakistan. Journal of Contemporary Issues in Business Research, 2(4), 124-134.

Botosan, C. A. (1997). Disclosure level and the cost of equity capital. The Accounting Review, 72(3), 323-349.

Elmans, S. (2012). Ownership structure and voluntary disclosure in Europe (Master thesis, Eramus University of Rotterdam, Holland). 
Fekete, S., Matis, D., \& Lukács, J. (2008). Factors influencing the extent of corporate compliance with IFRS - The case of Hungarian listed companies. Retrieved from http://papers.ssrn.com/sol3/papers.cfm?abstract_id=1295722

Hassan, M. ( 2013). Corporate governance characteristics and voluntary disclosure: The case of UAE listed corporations. Paper presented at the 2013 International Conference on business, Economics, and Accounting (2013 IBEA), Bangkok, Thailand, March 20-23, 2013.

Healy, P. M., \& Palepu, K. G. (2001). Information asymmetry, corporate disclosure, and the capital markets: A review of the empirical disclosure literature. Journal of Accounting and Economics, 31(1-3), 405-440.

Hossain, M., \& Hammami, H. (2009). Voluntary disclosure in the annual reports of an emerging country: The case of Qatar. Advances in Accounting, 25(2), 255-265.

Ianniello, G., Mainardi, M., \& Rossi, F. (2013). Corporate governance and auditor choice. Paper presented at the Bicentenary Conference, Lecce, Italy, September 19-21, 2013.

International Finance Corporation [IFC]. (2010). Corporate governance manual (2nd ed.). Hanoi.

International Organization of Securities Commissions [OICV-IOSCO]. (2002). Principles for ongoing disclosure and material development reporting by listed entities. A Statement of the Technical Committee of the International Organization of Securities Commissions, October 2002.

Jensen, M. C., \& Meckling, W. H. (1976). Theory of the firm: Managerial behavior, agency costs and ownership structure. Journal of Financial Economics, 3(4), 305-360.

Khodadadi, V., Khazami, S., \& Aflatooni, A. (2010). The effect of corporate governance structure on the extent of voluntary disclosure in Iran. Business Intelligence Journal, 3(2), 151-164.

Lan, Y., Wang, L., \& Zhang, X. (2013). Determinants and features of voluntary disclosure in the Chinese stock market. China Journal of Accounting Research, 6(4), 265-285.

Leng, J., \& Ding, Y. (2011). Internal control disclosure and corporate governance: Empirical research from Chinese listed companies. Technology and Investment, 2(4), 286-294.

Li, H., \& Qi, A. (2008). Impact of corporate governance on voluntary disclosure in chinese listed companies. Corporate Ownership \& Control, 5(2), 360-366.

Li, H., \& Zhao, P. (2011). A study of factors influencing voluntary disclosure of Chinese listed companies. M \& D Forum, 245-257.

Lokman, N. (2011). Impact of incentives to voluntarily disclose corporate governance information in annual reports: An empirical study of Malaysian publicly listed companies (Ph.D. thesis, School of Accounting, Economics and Finance, Unversity of Southern Queensland, Australia).

Madhani, P. M. (2007). Role of voluntary disclosure and transparency in financial reporting. In D. Alagiri, \& K. Mallela (Eds.), Corporate financial reporting - Changing scenario (pp. 75-81). Hyderabad, India: ICFAI University Press.

Nandi, S., \& Ghosh, S. K. (2013). Corporate governance attributes, firm characteristics and the level of corporate disclosure: Evidence from the Indian listed frims. Decision Science Letters, 2(1), 45-58.

Omran, M., \& Abdelrazik, M. (2013). The association between corporate governance and corporate disclosure: A critical review. Journal of Public Administration and Governance, 3(3), 94-107.

Qu, W. (2011). A study of voluntary disclosure by listed companies in China (Ph.D. thesis, Deakin University, Australia).

Rouf, A., \& Harun, A. (2011). Ownership structure and voluntary disclosure in annual reports of Bangladesh. Pakistan Journal of Commerce \& Social Sciences, 5(1), 129-139.

Rouf, M. A. (2011). An empirical investigation into corporate voluntary disclosure of management's responsibilities in the Bangladeshi listed companies. ASA University Review, 5(1), 261-274.

Sukthomya, D. (2011). The empirical evidence of voluntary disclosure in the annual reports of listed companies: The case of Thailand (Ph.D. thesis, the University of Nottingham, United Kingdom).

Thangatorai, R., Jaffar, R., \& Shukor, Z. A. (2011). The effect of corporate governance mechanism on the voluntary internet financial reporting: A case of Malaysia. Recent Advances in Management, Marketing and Finances, 81-86.

Vu, K. B. (2012). Determinants of voluntary disclosure for Vietnamese listed companies (Ph.D. thesis, Curtain University, Australia).

Yuen, D. C. Y., Liu, M., Zhang, X., \& Lu, C. (2009). A case study of voluntary disclosure by Chinese enterprises. Asian Journal of Finance and Accounting, 1(2), 118-145.

Zaheer, N. (2013). Effects of duality, board size and board composition on corporate governance disclosure in Pakistan. International SAMANM Journal of Finance and Accounting, 1(3), 1-16.

Zhang, J. (2013). Determinants of corporate environmental and social disclosure in Chinese listed mining, electric supply and chemical companies annual reports (Master thesis, Edith Cowan University, Australia). 
Appendix 1: List of Vietnamese Voluntary Disclosure Index (42 items)

\begin{tabular}{|c|c|}
\hline No. & Item \\
\hline \multicolumn{2}{|c|}{ Corporate and Strategic Information (11 items) } \\
\hline 1 & Statement of strategy and objectives \\
\hline 2 & Discussion on the impact of strategy on current results \\
\hline 3 & Discussion on the impact of strategy on future results \\
\hline 4 & Discussion of research and development activities \\
\hline 5 & Statements of strategy improving business \\
\hline 6 & Discussion of future product developments \\
\hline 7 & Rate of return on expected projects \\
\hline 8 & Descriptive information of marketing network (domestic market) \\
\hline 9 & Descriptive information of marketing network (foreign market) \\
\hline 10 & Discussion of competitive environment \\
\hline 11 & General discussion of industry trends (past) \\
\hline \multicolumn{2}{|c|}{ Financial and Capital Market Information (14 items) } \\
\hline 1 & Cash flow \\
\hline 2 & Dividend policy \\
\hline 3 & Market share analysis \\
\hline 4 & Share price and volume of shares traded information \\
\hline 5 & Main advantages \\
\hline 6 & Weaknesses \\
\hline 7 & Competitors analysis \\
\hline 8 & Discussion of advertising, marketing activities \\
\hline 9 & Discussion on the effects of inflation rates on current results \\
\hline 10 & Discussion on the effects of foreign currency on current results \\
\hline 11 & Discussion on the effects of interest rates on current results \\
\hline 12 & Breakdown and analysis of sales and revenues \\
\hline 13 & Breakdown and analysis of operating expenses \\
\hline 14 & Breakdown and analysis of administrative expenses \\
\hline \multicolumn{2}{|c|}{ Forward Looking Information (8 items) } \\
\hline 1 & Forecast assumptions \\
\hline 2 & General discussion of future industry trend \\
\hline 3 & Discussion of external factors affecting the company's future (economy/politics) \\
\hline 4 & Forecast of cash flows \\
\hline 5 & Discussion on future expenditure \\
\hline 6 & Discussion on the effects of interest rates on future operating activities \\
\hline 7 & Discussion on the effects of inflation on future operating activities \\
\hline 8 & Discussion on the effects of foreign currency on future operating activities \\
\hline \multicolumn{2}{|c|}{ Social Reporting Information (9 items) } \\
\hline 1 & Employee training \\
\hline 2 & Number of employees trained \\
\hline 3 & Employee benefits \\
\hline 4 & Labor protection policy \\
\hline 5 & Environmental protection policy \\
\hline 6 & Community policy \\
\hline 7 & Data on accidents \\
\hline 8 & Discussion of workplace safety \\
\hline 9 & Discussion on the safety of the products \\
\hline
\end{tabular}

